\title{
Seasonal changes in expression of nerve growth factor and its receptors TrkA and p75 in the ovary of wild ground squirrel (Citellus dauricus Brandt)
}

Ben $\mathrm{Li}^{1}$, Xia Sheng ${ }^{1}$, Lihong Bao ${ }^{2}$, Shiyang Huang ${ }^{1}$, Qinglin $\mathrm{Li}^{1}$, Yuning Liu', Yingying Han ${ }^{1}$, Gen Watanabe ${ }^{3}$, Kazuyoshi Taya ${ }^{3}$ and Qiang Weng ${ }^{1^{*}}$

\begin{abstract}
The aim of this study was to investigate the presence of nerve growth factor (NGF) and its receptors tyrosine kinase A (TrkA) and p75 in the ovaries of the wild ground squirrels during the breeding and nonbreeding seasons. In the breeding period, NGF, TrkA and p75 were immunolocalized in granulosa cells, thecal cells, interstitial cells and luteal cells whereas in the nonbreeding period, both of them were detected only in granulosa cells, thecal cells and interstitial cells. Stronger immunostaining of NGF, TrkA and p75 were observed in granulosa cells, thecal cells and interstitial cells in the breeding season compared to the nonbreeding season. Corresponding for the immunohistochemical results, immunoreactivities of NGF and its two receptors were greater in the ovaries of the breeding season then decreased to a relatively low level in the nonbreeding season. The mean mRNA levels of NGF, TrkA and p75 were significantly higher in the breeding season than in the nonbreeding season. In addition, plasma gonadotropins, estradiol-17 $\beta$ and progesterone concentrations were significantly higher in the breeding season than in the nonbreeding season, suggesting that the expression patterns of NGF, and TrkA and p75 were correlated with changes in plasma gonadotropins, estradiol-17 $\beta$ and progesterone concentrations. These results indicated that NGF and its receptors, TrkA and p75 may be involved in the regulation of seasonal changes in the ovarian functions of the wild ground squirrel.
\end{abstract}

Keywords: Ground squirrel, NGF, Ovary, p75, TrkA

\section{Introduction}

The nerve growth factor (NGF) belongs to a family of related proteins required for the survival, maintenance, and development of discrete neuronal populations in the central and peripheral nervous systems [1-3]. It is also believed that NGF not only has an effect on the nervous system, but also plays an important role in a variety of non-neuronal system, such as immune, cardiovascular and endocrine systems [4-6]. The effect of NGF has been shown to be mediated through specific membrane receptors high-affinity tyrosine kinase A (TrkA), which is responsible for its biological activities $[7,8]$. Furthermore, the effect of NGF is also mediated via low affinity receptor $\mathrm{p} 75$ that also functions as other neurotropins' receptor [9]. When p75 and TrkA

\footnotetext{
* Correspondence: qiangweng@bjfu.edu.cn

'Laboratory of Animal Physiology, College of Biological Science and

Technology, Beijing Forestry University, Beijing 100083, China

Full list of author information is available at the end of the article
}

receptors are co-expressed, p75 increases the sensitivity of the TrkA receptor and its signaling efficiency $[10,11]$.

It is now well known that NGF and its receptors are expressed in the mammalian ovary, including women [12-14], rats [14,15], golden hamsters [16-18], cows [19], sheep [20] and Shiba goats [21]. More and more evidences have indicated that NGF signaling plays a critical role in the development of mammalian ovary, oogenesis and folliculogensis [22-24], in an auto- and/or paracrine manner. In our previous studies of the golden hamsters, NGF and its two receptors TrkA and p75 were present in ovaries, oviducts and uteri, demonstrating that NGF, TrkA and p75 have important autocrine and paracrine regulatory roles in the function of reproductive organs during the estrous cycle $[16,25,26]$. Data to support this concept in wild animals, however, is very limited. To study the basic mechanisms of NGF regulation of ovarian function during the breeding and nonbreeding seasons within the annual 
reproductive cycle, the wild ground squirrel offers a useful model without any manipulations.

The wild ground squirrel (Citellus dauricus Brandt) is a typical seasonal breeder which has a strict and extremely compressed breeding period (for female individuals, it includes estrous period, pregnancy and birth) from April to May and a long period of sexual dormancy from June to the following March including a 6-month hibernation period [27]. The wild female ground squirrel exhibits estrus immediately after emergence from hibernation in spring, and has a gestation period of 28 days [28]. Whether fertilized or not, all females become sexually inactive as the relatively brief breeding season ends. Previously, we observed the presence of inhibin/activin subunits in the ovary of the wild ground squirrels, indicating its important paracrine/autocrine regulatory role in the seasonal folliculogenesis of the wild ground squirrel [29]. In search for other key local players, we investigated the expression levels and immunolocalization of NGF and its receptors, TrkA and p75 in ovarian tissues of the wild ground squirrel during the breeding and nonbreeding seasons, and to elucidate the relationship between NGF and its receptors (TrkA and p75) and ovarian functions in this wild rodent.

\section{Material and methods \\ Animals}

All the procedures on animals were carried out in accordance with the Policy on the Care and Use of Animals by the Ethical Committee, Beijing Forestry University and approved by the Department of Agriculture of Hebei province, PR China (JNZF11/2007). Wild female ground squirrels that were regarded as adults according to their body weights (242-412 g) were captured on April 13 (10.2 hours of daylight) after emergence from hibernation in the breeding period $(\mathrm{n}=10)$ and on June 9 (12.6 hours of daylight) in the nonbreeding period $(n=8)$ of 2009 in Hebei Province, PR China.

Animals were anesthetized with $4 \%$ isoflurane and blood samples were rapidly collected from leg vein. Plasma samples were frozen and stored at $-20 \mathrm{C}$, after the blood samples were added heparin sodium and centrifuged (3000 rpm, $20 \mathrm{~min}$ at 4C). An overdose of pentobarbital was applied afterwards for euthanasia. Ovary and brain were quickly removed and dissected. Length, width and weight of each ovary were measured. A part of the tissues were fixed in $0.05 \mathrm{M}$ phosphate-buffered saline (PBS, $\mathrm{pH}$ 7.4) containing 4\% paraformaldehyde for histological and immunohistochemical observation, while the rest were immediately frozen in liquid nitrogen and stored at $-80 \mathrm{C}$ for RNA isolation and protein extraction.

\section{Histology}

Ovarian samples were dehydrated in ethanol series and embedded in paraffin wax. Serial sections $(4 \mu \mathrm{m})$ were mounted on slides coated with poly-L-lysine (Sigma, St. Louis, MO, U.S.A.). Sections were stained with hematoxylin-eosin (HE) for observations of general histology. The sections were screened using an Olympus photomicroscope with $\mathrm{a} \times 20$ objective lens and imaged with software Image-Pro Plus 4.5 (Media Cybernetics, Bethesda, MD, USA). Every one in ten serial sections, and altogether 50 and 30 sections for the breeding and nonbreeding season ovary respectively were selected for follicle identification [30] and quantification. Six random vision fields were selected per Section.

\section{Immunohistochemistry}

Ovarian sections were blocked with $10 \%$ normal goat serum to prevent the non-specific binding of the second antibody. The sections were then incubated with polyclonal primary antibody against NGF $(0.4 \mu \mathrm{g} / \mathrm{ml}, \mathrm{M}-20)$, TrkA $(2 \mu \mathrm{g} / \mathrm{ml}, 763)$ or p75 (2 $\mu \mathrm{g} / \mathrm{ml}, \mathrm{H}-92)$ (Santa Cruz Biotechnology, Santa Cruz, CA, USA) for $12 \mathrm{~h}$ at $4 \mathrm{C}$, and incubated with the second antibody, goat anti-rabbit IgG conjugated with biotin and peroxidase with avidin for $1 \mathrm{~h}$ at room temperature. The sections were visualized using a rabbit ExtrAvidin ${ }^{\text {Tw }}$ staining kit (Sigma, St. Louis, MO, USA) in $150 \mathrm{ml}$ of $0.05 \mathrm{M}$ Tris- $\mathrm{HCl}$ buffer containing $30 \mathrm{mg}$ 3,3diaminobenzidine (Wako, Tokyo, Japan) plus $30 \mu \mathrm{l} \mathrm{H}_{2} \mathrm{O}_{2}$. Finally, the sections were counterstained with hematoxylin (Merck, Tokyo, Japan) and NGF, TrkA and p75 were detected, respectively. The immunostained slides were scanned using the software Image-Pro Plus 4.5 (Media Cybernetics, MD, USA) at 20× magnification. The specificity of NGF and its receptors, TrkA and p75 antibodies have been described previously [31]. The immunohistochemical staining was determined as positive $(+)$, strong positive $(++)$, very strong positive $(+++)$, and negative $(-)$. Staining that was weak but higher than control was set as positive $(+)$; the highest intensity staining was set as very strong positive $(+++)$; staining intensity between + and +++ was set as strong positive $(++)$.

\section{Western blotting}

Ovarian tissues were weighed and dissected into small pieces using a clean razor blade. The tissues were homogenized in a tissue homogenizer containing $300 \mu \mathrm{l}$ of $10 \mathrm{mg} / \mathrm{ml}$ PMSF and incubated for $30 \mathrm{~min}$ on ice. Homogenates were centrifuged at $12,000 \mathrm{~g}$ for $10 \mathrm{~min}$ at 4C. Protein extracts $(25 \mu \mathrm{g})$ were mixed with equal volumes of $2 \times$ Laemmli sample buffer. Equal amounts of proteins from each sample were loaded onto a $12 \%$ SDSPAGE gel and electrophoretically separated at $18 \mathrm{~V} / \mathrm{cm}$ and transferred to nitrocellulose membrane using a wet transblotting apparatus (Bio-Rad, Richmond, CA, USA). The membrane was blocked in 3\% BSA for $1 \mathrm{~h}$ at room temperature. Primary incubation of the membrane was carried out using NGF, TrkA or p75 antibody (1:1000 
dilution) for $1 \mathrm{~h}$ at room temperature. Secondary incubation of the membrane was then carried out using an IRDye (1:5000 dilution, Rockland, Gilbertsville, PA, USA) for $1 \mathrm{~h}$ at room temperature. Finally, the membrane was washed in $25 \mathrm{ml}$ Tris-Buffered Saline with Tween-20 (TBST wash buffer, $0.02 \mathrm{M}$ Tris, $0.137 \mathrm{M} \mathrm{NaCl}$ and $0.1 \%$ Tween-20, $\mathrm{pH}$ 7.6) plus $3 \mu \mathrm{H}_{2} \mathrm{O}_{2}$ and visualized with Odyssey infrared imaging system. Brain tissue of wild ground squirrel was used as a positive control and water, instead of primary antisera, was used as a negative control. $\beta$-actin was selected as the endogenous control. The intensities of the bands were quantified using Quantity One software (Version 4.5, Bio-Rad Laboratories) and expression ratios were calculated.

\section{RNA isolation}

Total RNA from each sample was extracted using ISOGEN (Nippon Gene, Toyama, Japan). Approximately $1 \mathrm{~g}$ of ovarian tissues were thawed and immediately homogenized in $10 \mathrm{ml}$ of ISOGEN ${ }^{\mathrm{Tm}}$. The homogenate was incubated for $5 \mathrm{~min}$ at room temperature to allow the complete dissociation of nucleoprotein complexes. After the addition of $2 \mathrm{ml}$ of chloroform, the mixture was vigorously shaken for $3 \mathrm{~min}$ at room temperature and centrifuged at $12,000 \mathrm{~g}$ for $10 \mathrm{~min}$ at $4 \mathrm{C}$. The aqueous phase was then transferred to a fresh tube and washed with an equal volume of chloroform. An equal volume of isopropanol was added, and the sample was kept for $10 \mathrm{~min}$ at room temperature. RNA was precipitated by centrifugation at $12,000 \mathrm{~g}$ for $10 \mathrm{~min}$ at $4 \mathrm{C}$. The RNA pellet was washed twice with $75 \%$ ethanol, briefly dried under air, and dissolved in $100 \mu \mathrm{l}$ of diethylprocarbonatetreated water.

\section{Reverse transcription-polymerase chain reaction (RT-PCR)} The first-strand cDNA from total RNA was synthesized using Superscript II Reverse Transcriptase (Invitrogen, Carlsbad, CA, USA) and oligo $(\mathrm{dT})_{12-18}$ according to the manufacturer's protocol. The $20 \mu \mathrm{l}$ of reaction mixture contained $4 \mu \mathrm{g}$ of total RNA, $0.5 \mu \mathrm{g}$ of oligo $(\mathrm{dT})_{12-18}, 2.5 \mathrm{mM} \mathrm{MgCl} 2,0.5 \mathrm{mM}$ dNTP, $10 \mathrm{mM}$ dithiothreitol, $20 \mathrm{mM}$ Tris- $\mathrm{HCl}(\mathrm{pH} \mathrm{8.4)}$ ) and $200 \mathrm{U}$ of Superscript II enzyme. The first-strand cDNA was used for PCR amplification with the appropriate primers previously proved (Table 1). Given the unknown

Table 1 Oligonucleotide primer sequences for PCR amplifications

\begin{tabular}{lll}
\hline Primer & Sense & Antisense \\
\hline NGF & TCCACCCACCCAGTCTTC & GCTCGGCACTTGGTCTCA \\
TrkA & TCGGACCATGCTGCCCATCC & AGGCGTTGCTGCGGTTCTCG \\
p75 & GGAGGACACGAGTCCTGAGC & CAGTGGAGAGTGCTGCAAAG \\
RpL 7 & TCAATGGAGTAAGCCCAAAG & CAAGAGACCGAGCAATCAAG \\
\hline
\end{tabular}

genome of the wild ground squirrel, we could only design primers based on the sequence of mouse and rat [31], considering the relative conserved sequences between these rodents. The $100 \mu \mathrm{l}$ of reaction mixture contained $1 \mu \mathrm{l}$ of first-strand cDNA, $0.5 \mu \mathrm{M}$ each primer, $1.5 \mathrm{mM} \mathrm{MgCl}_{2}, 0.2 \mathrm{mM}$ dNTP, $20 \mathrm{mM}$ Tris- $\mathrm{HCl}(\mathrm{pH} 8.4)$ and $2.5 \mathrm{U}$ of Taq polymerase (Invitrogen, Carlsbad, CA, USA). The amplification was under the following condition: $94 \mathrm{C}$ for $5 \mathrm{~min}$ for the initial denaturation of the RNA/cDNA hybrid, 30 cycles of $94 \mathrm{C}$ for $1 \mathrm{~min}, 52 \mathrm{C}$ for $1 \mathrm{~min}$, and $72 \mathrm{C}$ for $2 \mathrm{~min}$ for amplification. The PCR product was electrophoresed in the $2 \%$ agarose gel and individual bands were visualized by ethidium bromide staining. Brain tissue of wild ground squirrel was used as positive control and water, instead of cDNA, was used as negative control. The housekeeping gene, $R p L 7$, was selected as the endogenous control as it is an estrogen-independent gene. The bands were quantified using Quantity One software (Version 4.5, Bio-Rad Laboratories) and expression ratios were calculated.

\section{Cloning and sequencing of PCR products}

The purified PCR products were ligated into pCR 2.1TOPO (Invitrogen, Carlsbad, CA, USA) and the ligation products were used to transform the competent $E$. coli using TOPO TA Cloning Kit (Invitrogen, Carlsbad, CA, USA). Plasmids were extracted from the bacteria and positive clones containing the proper insert were sequenced in both directions using Thermo Sequenase II Dye Terminator Cycle Sequencing Premix Kit (Amershan Pharmacia Biotech, UK) with an automatic sequencing system (ABI PRISM 377, Applied Biosystems Japan, Tokyo, Japan). After obtaining the sequence of each PCR product, we blasted with the known mRNA sequences of mouse (NGF, NM_013609.3; TrkA, NM_001033124.1; p75, NM_033217.3; RpL7, NM_011291.5), rat (NGF, NM_0012 77055.1; TrkA, NM_021589.1; p75, NM_012610.2; RpL7, NM_001100534.1), bovine (NGF, NM_001099362.1; TrkA, XM_005898751.1; p75, NM_001102478.2; RpL7, NM_001 014928.1) and human (NGF, NM_002506.2; TrkA, AB0194 88.2; p75, NM_002507.3; RpL7, NM_000971.3), find the homologous sequence fragments in each species and compare for homology using DNAman.

\section{Hormone assays}

Plasma concentrations of estradiol-17 $\beta$ and progesterone were determined by double-antibody RIA systems using ${ }^{125}$ I-labeled radioligands as described previously [32]. Antisera against estradiol-17 $\beta$ (GDN 244) [33] and progesterone (GDN 337) [34] was kindly provided by Dr. G. D. Niswender (Animal Reproduction and Biotechnology, Colorado State University, Fort Collins, $\mathrm{CO})$. The intra- and inter-assay coefficients of variation were $3.7 \%$ and $6.2 \%$ for estradiol- $17 \beta$ and $6.3 \%$ 
and $15.4 \%$ for progesterone, respectively. Plasma concentrations of follicle stimulating hormone (FSH) and luteinizing hormone $(\mathrm{LH})$ were measured by doubleantibody RIA systems using a rabbit antiserum against human FSH (\#6; provided by NIDDK NIH, Bethesda, $\mathrm{MD}, \mathrm{USA}$ ) and a rabbit antiserum against ovine $\mathrm{LH}$ (YM \#18; provided by Dr Y. Mori, Laboratory of Veterinary Ethology, University of Tokyo, Tokyo, Japan). The intra- and inter-assay coefficients of variation were $9.2 \%$ and $13.2 \%$ for $\mathrm{FSH}$ and $8.8 \%$ and $13.0 \%$ for $\mathrm{LH}$, respectively.

\section{Statistical analysis}

Means and standard deviations were calculated. Data were analyzed using a one-way ANOVA and the means were compared for significance using Duncan's Multiple Range Test $(\mathrm{P}=0.05)$ using the SPSS computer software package.

\section{Results}

\section{The distinct variation in ovarian histology and} folliculogenesis

Ovaries of breeding and nonbreeding seasons were observed morphologically and histologically (Figure 1). In line with our previous reports, both the ovarian volume and weight were markedly higher in the breeding season than in the nonbreeding season (Figure 1a and $b, p<0.01)$. All levels of follicles, as well as the corpora lutea, were seen in the breeding season ovary (Figure 1c), whereas primary and secondary follicles comprised most of the nonbreeding season ovary, with few tertiary and mature follicles (Figure 1d). Based on the HE staining of the serial sections, we also quantified the numbers of different levels of follicles and corpora lutea (Figure 1e and f). Apparently, the lower ratio of primary follicles and higher ratios of secondary, tertiary, mature follicles and corpora lutea implied a more active follicuologenesis in the breeding period ovary. The distinct folliculogenesis of the breeding and nonbreeding seasons were schemed respectively in Figure $1 \mathrm{~g}$ and $\mathrm{h}$.

\section{The ovarian immunoreactivity of NGF, TrkA and p75 changes seasonally}

Immunohistochemistry was performed to detect the localization pattern of NGF and its receptors in the wild ground squirrel ovary and representative stainings were shown in Figure 2. In the breeding season, both NGF ligand and TrkA receptor were present in various types of cells, including the granulosa cells, theca cells, interstitial cells and corpora lutea, with the highest intensity in the granulosa cells (Figure 2b,c,f,g). Strong positive signals of p75 were also detected in these somatic cells, but not in the corpora lutea (Figure $2 \mathrm{~d}$ and $\mathrm{h}$ ). The immunostaining intensity generally decreased when it came to the nonbreeding season. NGF and TrkA were still positively stained in the secondary follicles of the nonbreeding season ovary, where mild signals of p75 were detected only in the granulosa and theca cells (Figure 2j,k,l). No signal was seen in the negative control panel (Figure 2a,e,i). The immunoreactivity of each staining was quantified and summarized in Table 2.

\section{The seasonal changes in ovarian protein and mRNA expressions of NGF, TrkA and p75}

We then moved on to detect the protein and mRNA expression levels of NGF, TrkA and p75 using Western
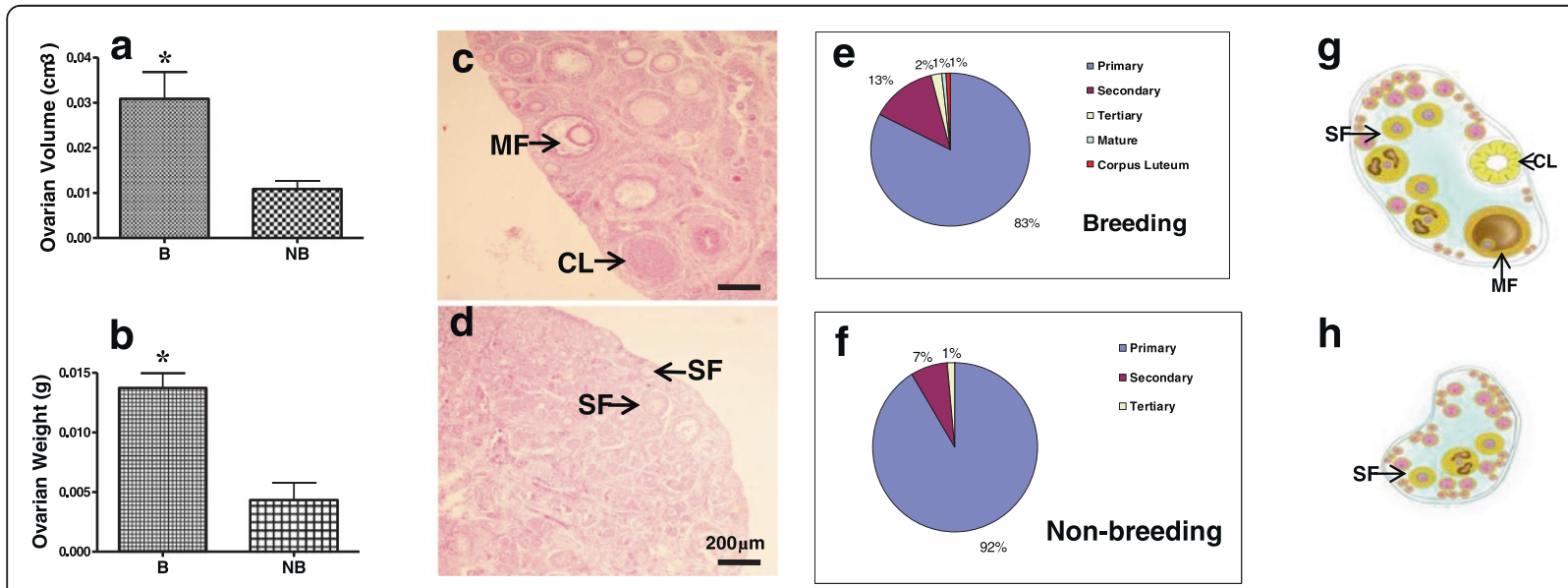

h

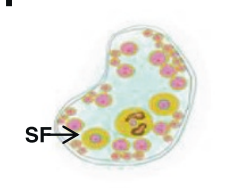

Figure 1 Morphological and histological features of ovarian tissues of the wild ground squirrel during the breeding and nonbreeding periods. Marked seasonal differences were observed in ovarian volume (a) and weight (b). Subsequently, HE staining was performed for the ovaries of the breeding season (c) and nonbreeding season (d), and follicles of the two periods were manually quantified accordingly (e and f) $\mathbf{g}$ and $\mathbf{h}$ were the schematic diagrams for the varied folliculogenesis of the breeding and nonbreeding periods. B, breeding season; NB, nonbreeding season; MF, mature follicle; $\mathrm{CL}$, corpus luteum; $\mathrm{SF}$, secondary follicle. * $\mathrm{P}<0.01$. 


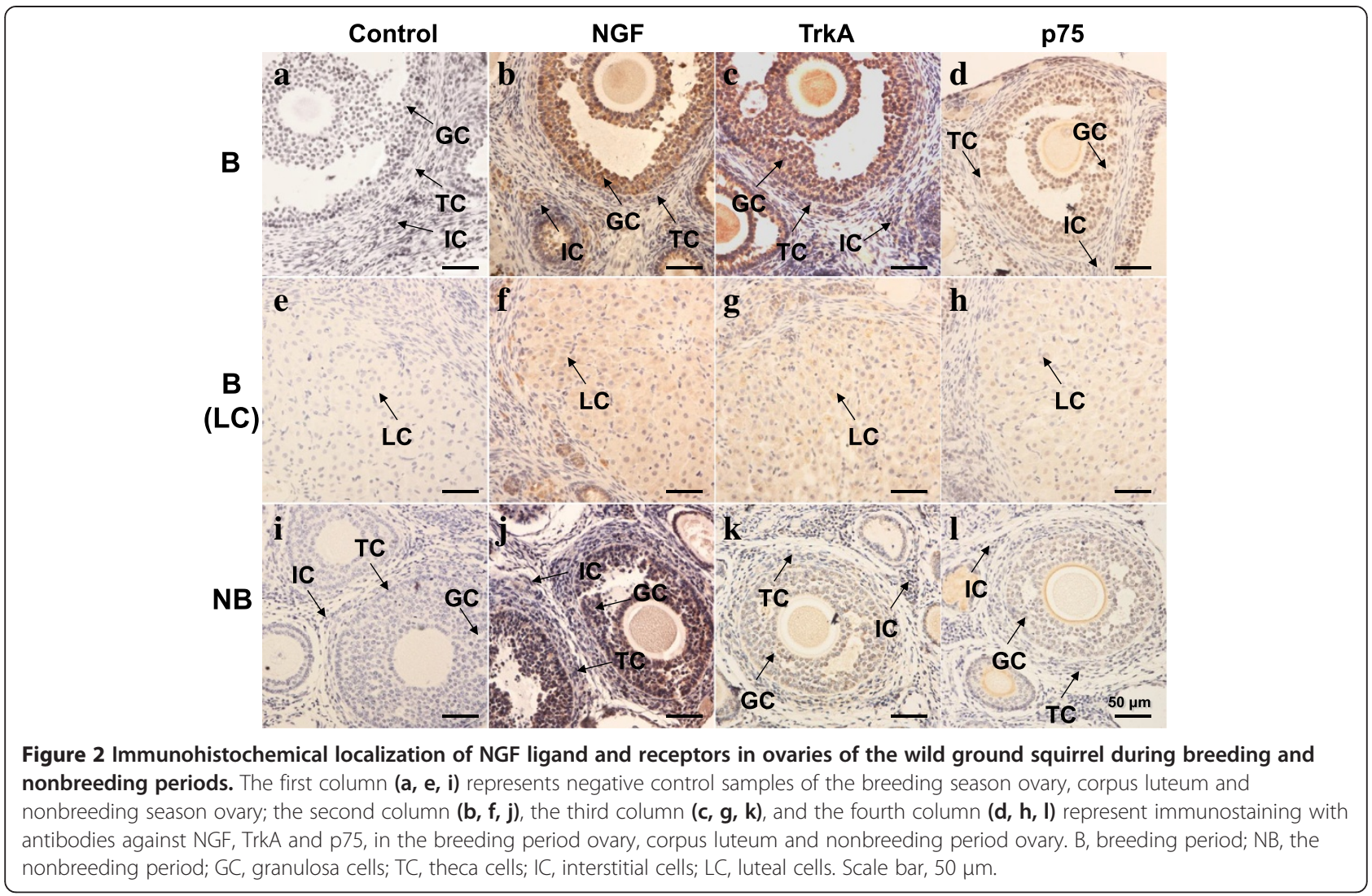

blot and PCR, and representative bands were shown in Figure 3 . The intensity of each band was normalized to the level of $\beta$-actin and RpL7, used as the endogenous control, for Western and PCR detections respectively. Both the protein and mRNA expression levels of NGF ligand and receptors were significantly higher in the breeding season when compared to the nonbreeding season, basically in consistent with the immunohistochemical results (Figure 3, $\mathrm{p}<0.01$ ). Notably, the relative protein level of NGF and the relative mRNA levels of NGF, TrkA and p75 were even higher in the breeding season ovary than in the brain $(P<0.05)$, reassuring the substantial role of NGF during this particular time.

Table 2 Relative abundance of NGF, TrkA, and p75 in ovaries of the wild ground squirrels during the breeding and nonbreeding seasons

\begin{tabular}{rccccccr}
\hline & \multicolumn{3}{c}{ NGF } & & \multicolumn{2}{c}{ TrkA } & \multicolumn{2}{c}{ p75 } \\
\hline & B & NB & B & NB & B & NB \\
Granulosa cells & +++ & ++ & +++ & + & ++ & + \\
Thecal cells & ++ & + & ++ & + & ++ & + \\
Interstitial cells & ++ & + & ++ & + & + & - \\
Lutein cells & ++ & $/$ & & ++ & / & - & \\
\hline
\end{tabular}

Immunoreactivity was shown as - for negative staining, + for the positive staining, ++ for the strong positive staining, +++ for the very strong positive staining and/for no such cell type.
To further confirm the nature of the PCR signals, cDNA fragments of NGF, TrkA and p75 in ovarian tissues were sequenced and compared to the corresponding fragments in mouse, rat, bovine, and human. The partial mRNA sequences in the wild ground squirrel are as below:

NGF\#

GGGGGACTCAGTGTGTGTGCTGGTGTCAGTGT GTGGGTTGGAGATAAGACCACAGCCACAGACA TCAAGGGCAAGGAGGTGACAGTGCTGGCCGAG GTGAACATTAACAACAGTGTATTCAGACAGTAC TTTTTTGAGACCAAGTGCCGAGC

TrkA\#

GGAAGTGACATCTCTACCGCAGTTCAGCACCGA GAGCGATGTGTGGAGCTTTGGGGTGGTGCTCT GGGAGATCTTCACCTATGGAAAGCAGCCCTGGT ACCAGCTCTCTAACACTGAGGCGATCGAGTGTA TCACGCAGGGCCGGGAGCTGGAGCGGCCGCGC GCCTGCCCTCCTGATGTCTACGCCATCATGCGA GGCTGCTGGCAGCGAGAACCGAATCAACGCCT P75\# CCAGTAGGGCAGTGTGGCGGAGCCTTGCGGAG CCATCCAGACCGTGTGTGAACCCTGCCTGGACA GTGTTACGTTCTCTGACGTGGTGAGCGCCACCG AGCCGTGCAAGCCGTGCACCGAGTGCCTGGGC CTGCAGAGTATGTCCGCTCCCTGTGTGGAGGCA 


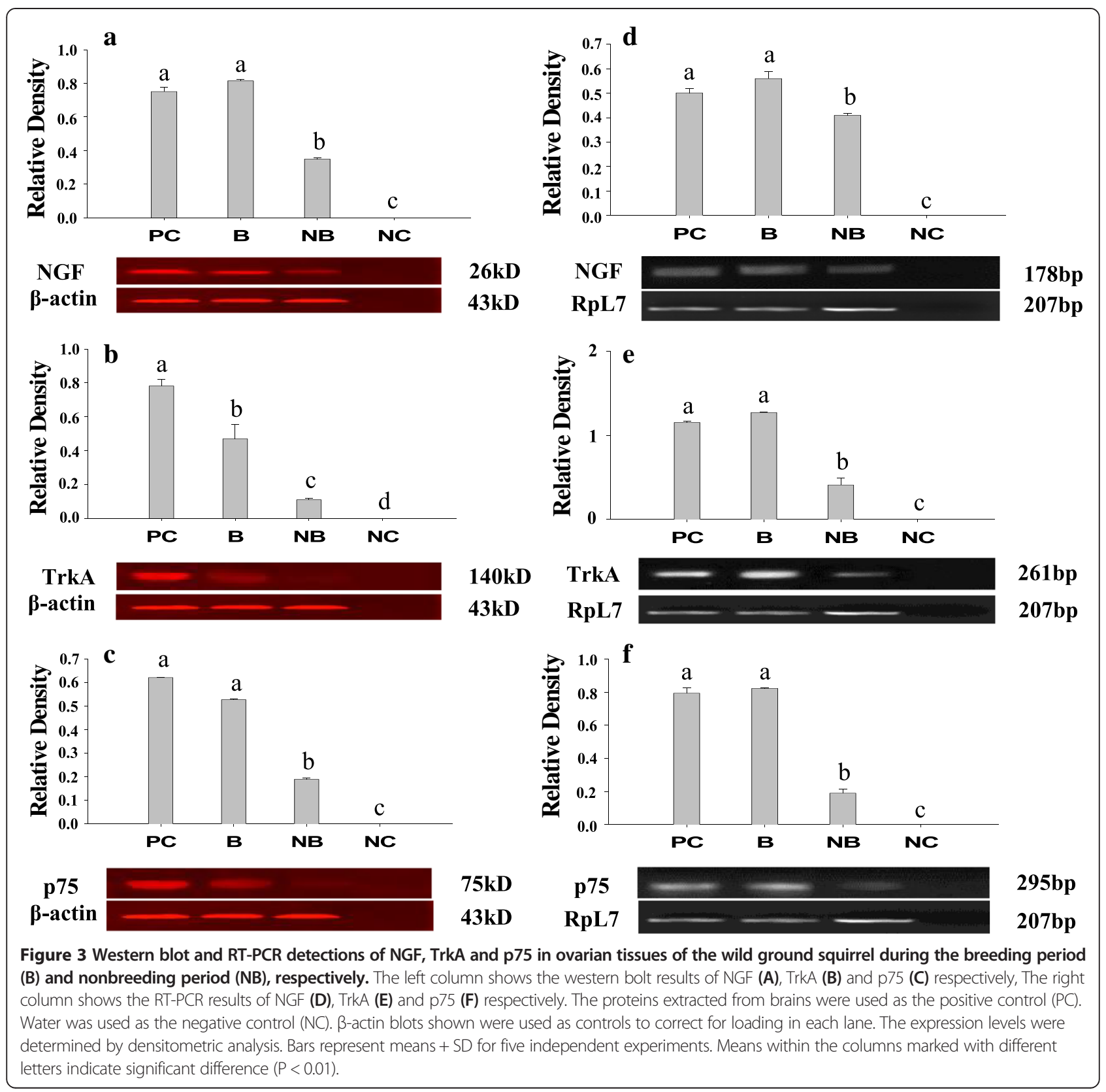

GACGATGCCGTGTGCCGATGCTCCTATGGCTAC TACCAGGACGAGGAGACTGGCCGCTGCGAGGC TTGCAGCGTGTGCGGGGTGGGCTCAGGATCGG TGTCCTCCC

RpL7\#

AAGGATCTGCTGCTGCTTCTGTTCCAGATCTCA ATGGCACCTTTGTTAAGCTCAACAAGGCTTCAA TTAACATGCTGCGGATTGTGGAGCCATACATTG CATGGGGGTACCCCAACCTGAAGTCAGTAAACG AGCTCATCTACAAGCGAGGCTACGGCAAAATCA ACAAGAAGCGGATTGCCTTGACAGATAATTCCT TGAATGCACGGTCTCTT
The 176-bp NGF cDNA nucleotide sequence identity was $92.11 \%, 90.20 \%, 81.70 \%$ and $86.18 \%$, respectively; the 261-bp TrkA cDNA nucleotide sequence identity was $94.32 \%, 90.83 \%, 84.72 \%$ and $83.41 \%$, respectively; the 295-bp p75 cDNA nucleotide sequence identity was $94.42 \%, 88.10 \%, 84.01 \%$ and $83.64 \%$, respectively; the 207-bp RpL7 cDNA nucleotide sequence identity was $94.55 \%, 84.65 \%, 74.23 \%$ and $76.87 \%$, respectively (Table 3 ), which not only confirmed the specificity of PCR primers but also suggested high affinities of NGF, TrkA and p75 genes between the wild ground squirrel and the species compared. 
Table 3 Nucleotide sequence identity in ovarian tissues of wild ground squirrel in comparison with mouse, rat, bovine and human (\%)

\begin{tabular}{lllll}
\hline & NGF & TrkA & p75 & RpL7 \\
\hline Mouse & 92.11 & 94.32 & 94.42 & 94.55 \\
Rat & 90.20 & 90.83 & 88.10 & 84.65 \\
Bovine & 81.70 & 84.72 & 84.01 & 74.23 \\
Human & 86.18 & 83.41 & 83.64 & 76.87 \\
\hline
\end{tabular}

Plasma concentration of $\mathrm{LH}, \mathrm{FSH}$, estradiol-17 $\beta$ and

\section{progesterone}

The profiles of plasma LH, FSH, estradiol-17 $\beta$ and progesterone are shown in Figure 4. Plasma LH, FSH, estradiol-17 $\beta$ and progesterone concentrations were all remarkably higher in the breeding season as compared to the nonbreeding period (Figure $4 \mathrm{a}, \mathrm{b}, \mathrm{c}, \mathrm{d}, \mathrm{p}<0.01$ ).

\section{Discussion}

The present study demonstrated that immunoreactivities of NGF and its two receptors, TrkA and p75 were greater in the ovaries of the breeding season then decreased to a relatively low level in the nonbreeding season, and the expression patterns of NGF ligand and receptors were correlated with the changes of plasma concentrations of gonadotropins, estradiol-17 $\beta$ and progesterone. These findings suggested that NGF, TrkA and p75 may be involved in the regulation of seasonal changes in the ovarian functions of the wild ground squirrels.

The present histological result was in agreement with previous data reported in this species, that the number of primary follicles had no significant difference
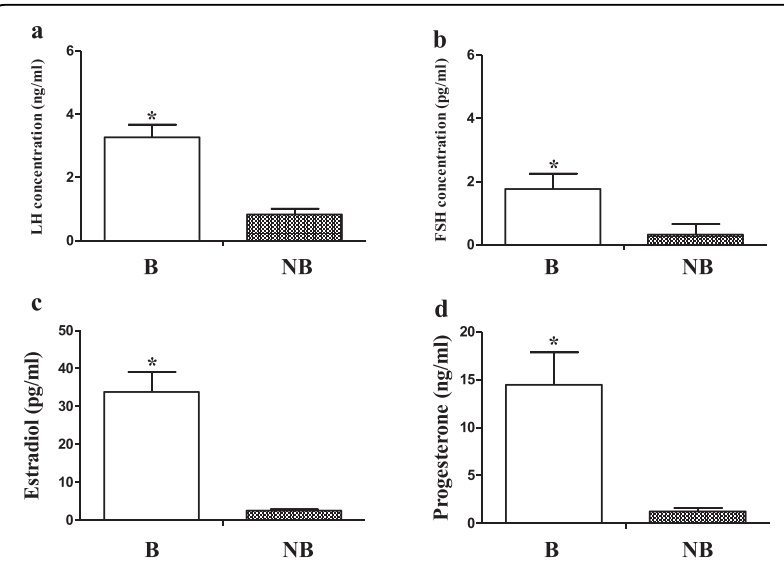

Figure 4 Seasonal change of the plasma concentration of $\mathrm{LH}$, FSH, estradiol-17 $\beta$ and progesterone. Plasma LH (a), FSH (b),

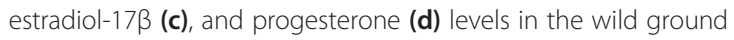
squirrel during breeding period (B) and nonbreeding period (NB). Bars represent means + SD for five independent experiments. Means within the columns marked with different letters indicate significant difference $(P<0.01)$. between the breeding and nonbreeding seasons, whereas the number of secondary follicles, antral follicles, post-antral follicles and corpus luteum displayed a significantly decrease from the breeding season to the nonbreeding season $[28,29]$. It suggested that primary follicles were stopped from developing to the stage of secondary follicles, antral follicles, post-antral follicles during nonbreeding season in the wild ground squirrel ovary. The fact that corpus luteum was not discovered in the nonbreeding season strongly suggested that no ovulation occurred in this stage [28]. In the present study, NGF and its receptors, TrkA and p75 were immunolocalized in ovarian tissues during the breeding and nonbreeding period, and both mRNA and protein of NGF, TrkA and p75 were also detected, indicating in situ synthesis and secretion of NGF and its receptors in ovaries of the wild ground squirrel, where the role of NGF might be mediated via both receptors to affect follicular development. Moreover, the expression levels of NGF and its receptors, TrkA and p75 were significantly higher in the breeding season as compared to the nonbreeding season, implying that NGF system may be involved in the regulation of ovarian function change. Our findings in the wild ground squirrel was generally in line with previous reports in pig and ewe, which showed higher contents of NGF and TrkA in large follicles than in smaller follicles $[20,35]$. Given the increased expression of NGF and its receptors in ovary of the breeding season, as well as the distinct morphological change, it is reasonable to postulate that NGF contributes to not only the innervation of rapidly growing follicles, but also steroidogenic cell proliferation and steroid production in the breeding season ovary, as has been observed in other rodents $[16,36,37]$.

The female reproductive system undergoes a number of programmed cyclical processes during the course of the ovulatory cycle. NGF and its receptors, under the influence of gonadotropins and/or ovarian hormones, may play a crucial regulatory role in these processes [25]. In the present study, the expression of NGF and its receptors were correlated with changes in plasma concentrations of LH, FSH, estradiol-17 $\beta$ and progesterone during the breeding and nonbreeding seasons. These results were similar to those found in golden hamsters and pigs. Previous studies in golden hamster have suggested that LH surge may be an important factor for inducing the expression of NGF, TrkA, p75 in ovarian tissues periodically $[16,18]$. In pig ovary, the increase in expression of NGF and TrkA in large follicles found on day 20 may also result from an LH effect [35]. Dissen et al. reported that in juvenile rats treated with equine chorionic gonadotropin, significantly elevated TrkA mRNA levels were found in ovary after the first preovulatory LH surge [38]. Similarly, the functional relationship between gonadotropins and 
NGF in studies of the sheep ovary showed that large follicles respond with increased NGF release to in vitro stimulation with a combination of LH and FSH [20]. Earlier studies also indicated that NGF activity and content were found to be increased by estradiol in a glioma cell line culture [39]. In addition, our previous studies showed that the expression of NGF, TrkA and p75 in the uterus of the wild ground squirrel was highest in the breeding season, when estradiol and progesterone production were greatest [31]. Taken together, the present results are in accordance with the views that NGF and its receptors are expressed in ovarian tissues, and these expressions are gonadotropins and/or ovarian hormones-dependent, and therefore, may contribute to events either led to or associated with the ovulatory process [13].

The present study showed that immunolocalization for NGF and its receptors were also found in luteal cells during the breeding season, which was similar to those observed in other species such as golden hamster [16], Shiba goat [21] and porcine [35]. In golden hamster, luteal cells displayed a stronger reaction for NGF and its receptors in metestrus than in estrus and diestrus [16]. In pig, the increased NGF and TrkA protein levels in luteal cells were found during the estrous cycle [35]. These results shed light to the critical role of NGF in development and/or maintenance of luteal function, which is further supported by the findings that NGF can stimulate of progesterone and oxytocin release [40] and acetylcholine production [41] in bovine luteal cells as well as maintenance of luteal vasculature in rats [37]. In line with these aforementioned data, our present results indicated that NGF ligand and receptors might play a similar role in the development of corpora lutea in the wild seasonally-breeding rodent.

Cellular growth is related to the ability to promote proliferation of mesenchyme and follicular cells, as well as to induce FSHR synthesis $[13,15]$. In our previous studies, the Western blotting results of FSHR showed that significant induction in the breeding season compared with the nonbreeding season [28]. This study revealed that the change levels of gonadotropins were parallel to those in the expression patterns of ovarian NGF and receptors during the breeding and the nonbreeding seasons. In rats, ovaries treated with NGF developed the capacity to response to FSH, with the formation of cAMP in preantral follicles [15]. Similar results were obtained in human cells, in which the culture of granulosa cells with NGF also increased expression of the FSHR in these cells [13]. These results implied that NGF may act indirectly in follicular development through the production of biologically active FSHR [13]. In golden hamsters, as one member of TGF $\beta$ superfamily, inhibin $\alpha$-subunit might works in concert with NGF and its receptors to act on LH/hCG receptor expression in ovarian interstitial cells and associated with the ovulatory process [18]. Also, our previous studies showed that inhibin/activin subunits $(\alpha, \beta(A)$ and $\beta(B))$ were present in granulosa cells, theca cells of antral follicles and interstitial cells in the breeding season ovary of wild ground squirrel, following ovulation, the corpora lutea become a major site of inhibin/activin synthesis [29]. Moreover, the expression patterns of inhibin/activin subunits in the wild ground squirrel ovary were also consistent with the present results. Thus, combined with previous reports, this study suggested that the co-expression of NGF and its receptors, along with other key growth factors, including inhibin/activin subunits, might indicate synergistic actions of them in the regulation of seasonal folliculogenesis in the wild ground squirrel.

In conclusion, we have shown, for the first time, the expression patterns of ovarian NGF, TrkA and p75 during the breeding and nonbreeding seasons in the wild ground squirrel. Our results revealed a close correlation between NGF expression and gonadotropins and steroid hormones, which implicated that NGF ligand and receptors are likely to be involved in the regulation of seasonal changes in the ovarian functions of the wild ground squirrel. The interesting alterations in ovarian morphology and histology as well as folliculogenesis observed between breeding and nonbreeding periods in the wild ground squirrel demonstrate a complex regulatory mechanism (s) that involves both sex steroids and growth factors.

\section{Competing interests}

The authors declare that they have no competing interests.

\section{Authors' contributions}

$\mathrm{BL}$ participated in performing the experiments, analyzing the data and drafting the manuscript. XS, LB, SH, QL and YL assisted with sample collection, all experiments and helped revising the manuscript. $\mathrm{YH}$ and $\mathrm{QW}$ designed, supervised the study, and revised manuscript. GW and KT provided some reagents and revised the manuscript. All authors read and approved the final manuscript.

\section{Acknowledgements}

This study is supported by a Grant-in-Aid from the Program for the Fundamental Research Funds for the Central Universities (BLYX2013024) and National Natural Science Foundation of China (NSFC, No. J1103516) from China.

\section{Author details}

${ }^{1}$ Laboratory of Animal Physiology, College of Biological Science and Technology, Beijing Forestry University, Beijing 100083, China. ${ }^{2}$ Institute of Public Health, Inner Mongolia University for Nationalities, Tongliao 028000, China. ${ }^{3}$ Department of Veterinary Medicine, Faculty of Agriculture, Laboratory of Veterinary Physiology, Tokyo University of Agriculture and Technology, Tokyo 183-8509, Japan.

Received: 20 September 2013 Accepted: 21 December 2013 Published: 9 January 2014

\section{References}

1. Angeletti $\mathrm{RH}$, Bradshaw RA: Nerve growth factor from mouse submaxillary gland: amino acid sequence. Proc Natl Acad Sci USA 1971, 68:2417-2420.

2. Levi-Montalcini R: The nerve growth factor 35 years later. Science 1987, 237:1154-1162. 
3. Snider WD: Functions of the neurotrophins during nervous system development: what the knockouts are teaching us. Cell 1994, 77:627-638.

4. Leon A, Buriani A, Dal Toso R, Fabris M, Romanello S, Aloe L, Levi-Montalcini R: Mast cells synthesize, store, and release nerve growth factor. Proc Natl Acad Sci USA 1994, 91:3739-3743.

5. Tessarollo L: Pleiotropic functions of neurotrophins in development Cytokine Growth Factor Rev 1998, 9:125-137.

6. Rosenbaum T, Vidaltamayo R, Sánchez-Soto MC, Zentella A, Hiriart M: Pancreatic beta cells synthesize and secrete nerve growth factor. Proc Natl Acad Sci USA 1998, 95:7784-7778.

7. Raffioni S, Bradshaw RA, Buxser SE: The receptors for nerve growth factor and other neurotrophins. Annu Rev Biochem 1993, 62:823-850.

8. Sutter A, Riopelle RJ, Harris-Warrick RM, Shooter EM: The heterogeneity of nerve growth factor receptors. Prog Clin Biol Res 1979, 31:659-667.

9. Dechant G, Barde YA: Signalling through the neurotrophin receptor p75NTR. Curr Opin Neurobiol 1997, 7:413-418.

10. Ibañez CF: Emerging themes in structural biology of neurotrophic factors. Trends Neurosci 1998, 21:438-444.

11. Friedman WJ, Greene LA: Neurotrophin signaling via Trks and p75. Exp Cell Res 1999, 253:131-142.

12. Anderson RA, Robinson LL, Brooks J, Spears N: Neurotrophins and their receptors are expressed in the human fetal ovary. $J$ Clin Endocrinol Metab 2002, 87:890-897.

13. Salas CM, Julio-Pieper $M$, Valladares $M$, Pommer R, Vega M, Mastronardi $C$, Kerr B, Ojeda SR, Lara HE, Romero C: Nerve growth factor-dependent activation of TrkA receptors in the human ovary results in synthesis of FSH receptors and estrogen secretion. J Clin Endocrinol Metab 2006, 91:2396-2403.

14. Dissen GA, Hirshfield AN, Malamed S, Ojeda SR: Expression of neurotrophins and their receptors in the mammalian ovary is developmentally regulated: changes at the time of folliculogenesis. Endocrinology 1995, 136:4681-4692.

15. Romero CA, Paredes A, Dissen GA, Ojeda SR: Nerve growth factor induces the expression of functional FSH receptors in newly formed follicles of the rat ovary. Endocrinology 2002, 143:1485-1494.

16. Shi Z, Jin W, Watanabe G, Suzuki AK, Takahashi S, Taya K: Expression of nerve growth factor (NGF) and its receptors TrkA and p75 in ovaries of the cyclic golden hamster (Mesocricetus auratus) and the regulation of their production by luteinizing hormone. J Reprod Dev 2004, 50:605-611.

17. Weng Q, Shi Z, Kawaguchi M, Watanabe G, Taya K: Expression of nerve growth factor and its receptors TrkA and p75 and inhibin alpha-subunit in the ovarian interstitial cells of lactating golden hamsters. J Reprod Dev 2008, 54:397-401.

18. Weng Q, Shi Z, Tukada J, Watanabe G, Taya K: Immunodetection of NGF, TrkA, p75 and inhibin alpha-subunit in interstitial cells of golden hamsters treated with hCG. J Reprod Dev 2009, 55:622-628.

19. Levanti MB, Germaná A, Abbate F, Montalbano G, Vega JA, Germaná G: TrkA and p75NTK in the ovary of adult cow and pig. J Anat 2005, 207:93-96.

20. Mattioli M, Barboni B, Gioia L, Lucidi P: Nerve growth factor production in sheep antral follicles. Domest Anim Endocrinol 1999, 17:361-371.

21. Ren LQ, Medan MS, Weng Q, Jin W, Li CM, Watanabe G, Taya K: Immunolocalizationof nerve growth factor (NGF) and its receptors (TrkA and p75LNGFR) in thereproductive organs of Shiba goats. J Reprod Dev 2005, 51:399-404.

22. Abir R, Fisch B, Jin S, Barnnet M, Ben-Haroush A, Felz C, Kessler-Icekson G, Feldberg D, Nitke S, Ao A: Presence of NGF and its receptors in ovaries from human fetuses and adults. Mol Hum Reprod 2005, 11:229-236.

23. Dissen GA, Romero C, Hirshfield AN, Ojeda SR: Nerve growth factor is required for early follicular development in the mammalian ovary. Endocrinology 2001, 142:2078-2086.

24. Chaves RN, Alves AM, Lima LF, Matos HM, Rodrigues AP, Figueiredo JR: Role of nerve growth factor (NGF) and its receptors in folliculogenesis. Zygote 2013, 21:187-197.

25. Weng Q, Shi Z, Watanabe G, Taya K: Immunolocalization of NGF and its receptors TrkA and p75 in the oviducts of golden hamsters during the estrous cycle. Exp Anim 2009, 58:543-546.

26. Shi Z, Arai KY, Jin W, Weng Q, Watanabe G, Suzuki AK, Taya K: Expression of nerve growth factor and its receptors NTRK1 and TNFRSF1B is regulated by estrogen and progesterone in the uteri of golden hamsters. Biol Reprod 2006, 74:850-856.
27. Pudney J, Canick JA, Clifford NM, Knapp JB, Callard GV: Location of enzymes of androgen and estrogen biosynthesis in the testis of the ground squirrel. Biol Reprod 1985, 33:971-980.

28. Li X, Zhang H, Sheng X, Li B, Zhou J, Xu M, Weng Q, Watanabe G, Taya K: Immunoreactivities of androgen receptor, estrogen receptors, P450arom, P450c17 proteins in wild ground squirrels ovaries during the nonbreeding and breeding seasons. J Ovarian Res 2012, 5:26. 10.1186/ 1757-2215-5-26

29. Sheng X, Weng J, Zhang H, Li X, Zhang M, Xu M, Weng Q, Watanabe G, Taya T: Immunohistochemical localization of inhibin/activin subunits in the wild ground squirrel (Citellus dauricus Brandt) ovary. J Reprod Dev 2012, 58:531-536.

30. McGee EA, Hsueh AJ: Initial and cyclic recruitment of ovarian follicles. Endocr Rev 2000, 21:200-214.

31. Li B, Sheng X, Song M, Zhang H, Weng J, Zhang M, Hu X, Zhou J, Xu M Weng Q, Watanabe G, Taya K: Expression of nerve growth factor and its receptors TrkA and p75 in the uterus of wild female ground squirrel (Citellus dauricus Brandt). Gen Comp Endocri 2012, 176:62-69.

32. Taya K, Watanabe G, Sasamoto S: Radioimmunoassay for progesterone, testosterone and estradiol-17b using 125I-iodohistamine radioligands. Jpn J Anim Reprod 1985, 31:186-197.

33. Korenman SG, Stevens RH, Carpenter LA, Robb M, Niswender GD, Sherman BM: Estradiol radioimmunoassay without chromatography: procedure, validation and normal values. J Clin Endocrinol Metab 1974, 38:718-720.

34. Gibori G, Antczak E, Rothchild I: The role of estrogen in the regulation of luteal progesterone secretion in the rat after day 12 of pregnancy. Endocrinology 1977, 100:1483-1495.

35. Jana B, Koszykowska M, Czarzasta J: Expression of nerve growth factor and its receptors, TrkA and p75, in porcine ovaries. J Reprod Dev 2011, 57:468-474.

36. Dissen GA, Lara HE, Leyton V, Paredes A, Hill DF, Costa ME, Martinez-Serrano A, Ojeda SR: Intraovarian excess of nerve growth factor increases androgen secretion and disrupts estrous cyclicity in the rat. Endocrinology 2000, 141:1037-1082.

37. Julio-Pieper M, Lara HE, Bravo JA, Romero CA: Effects of nerve growth factor (NGF) on blood vessels area and expression of the angiogenic factors VEGF and TGF beta1 in the rat ovary. Reprod Biol Endocrinol 2006 10:57-61.

38. Dissen GA, Hill DF, Costa ME, Les Dees CW, Lara HE, Ojeda SR: A role for TrkA nerve growth factor receptors in mammalian ovulation. Endocrinology 1996, 137:198-209.

39. Perez-Polo JR, Hall K, Livingston K, Westlund K: Steroid induction of nerve growth factor synthesis in cell culture. Life Sci 1977, 21:1535-1544.

40. Miyamoto A, Okuda K, Schweigert FJ, Schams D: Effects of basic fibroblast growth factor, transforming growth factor-beta and nerve growth factor on the secretory function of the bovine corpus leteum in vitro. J Endocrinol 1992, 135:103-114.

41. Al-Zi'abi MO, Bowolaksono A, Okuda K: Survival role of locally produced acetylcholine in the bovine corpus luteum. Biol Reprod 2009, 80:823-832.

doi:10.1186/1757-2215-7-3

Cite this article as: Li et al.: Seasonal changes in expression of nerve growth factor and its receptors TrkA and p75 in the ovary of wild ground squirrel (Citellus dauricus Brandt). Journal of Ovarian Research 2014 7:3.

\section{Submit your next manuscript to BioMed Central and take full advantage of:}

- Convenient online submission

- Thorough peer review

- No space constraints or color figure charges

- Immediate publication on acceptance

- Inclusion in PubMed, CAS, Scopus and Google Scholar

- Research which is freely available for redistribution 